\title{
THE AUTHORITARIAN LEGAL CULTURE AT WORK: THE PASSIVITY OF PARTIES AND THE INTERPRETATIONAL STATEMENTS OF SUPREME COURTS
}

\begin{abstract}
Zdeněk Kühn*
Summary: The purpose of this paper is to show that several rarely discussed features of the legal culture in Central and Eastern Europe distinguish this region from its Western counterpart. First, there is the misunderstanding of the classical Continental principle of Iura novit curia, the maxim which tells us that it is the judge who knows the law. While the activity of parties and their close collaboration in discussing issues of law with the judge is an important engine in applying European law in the old EU of 15, the parties are often viewed as passive objects in post-Communist litigation. Second, there is the specific idea of interpretational statements issued by post-Communist supreme courts irrespective of any real-life pending case. My thesis is that both these phenomena have a concrete philosophical and historical underpinning which constitutes one of the deep differences between the conception of law in Europe's East and Europe's West.
\end{abstract}

I.

Communist dictatorship, as any other sort of dictatorship, necessarily generated an authoritarian understanding of law, as explained by Professor Siniša Rodin:

Instead of rational discourse that shaped the legal and institutional landscape of Europe's West, the predominant discourse in Central and Eastern Europe was authoritarian. The main characteristic of such authoritarian discourse is the proclamation and imposition of one truth as universal and final. Such discourse was authoritarian since it purported to have a social monopoly over determining the meaning of legal and political language at the top of the political hierarchy and communicating it downward. It was, nevertheless, a dis-

\footnotetext{
* Assistant Professor, Charles University Law School, Prague, Czech Republic. Ph.D., Charles University Law School (2001); LL.M., University of Michigan Law School (2002); S.J.D. Candidate, University of Michigan Law School (2003). I owe my thanks for many ideas developed here to my discussions with Professors Eric Stein and Mathias Reimann of the University of Michigan Law School. All translations are mine unless otherwise indicated. I owe thanks to the Michigan Grotius Fellowship for its financial support.
} 
course, since communication of meaning defined in an authoritarian way was indispensable to support the claim of universal acceptance, the maintenance of which is a condition of the system's integrity. ${ }^{1}$

Authoritarian judicial discourse must be distinguished from authoritative judicial discourse. The judicial discourse of any legal system is inherently authoritative. This is the result of the facts 1) that by definition courts must decide as if there were one correct answer to the questions presented to the court (the judicial "one right answer" thesis), and 2) that judicial decisions are final because of their authority within the judicial and legal system. ${ }^{2}$ Authoritative judicial discourse does not preclude, but on the contrary presupposes, a pluralism of opinions and the participation of all competent persons in the legal decision-making process. Plurality of opinion and the fact that the court takes all relevant opinions seriously gives to the decision-maker of last resort the legitimacy to provide the "right" answer, which is a necessary condition for the discourse to remain authoritative.

In contrast, authoritarian discourse means something very different. Here, the pluralism of opinions is absent. The "right" answer is achieved through a "one-way" process and is backed entirely by threat and force. Those to whom decisions are addressed cannot participate in finding the "right" answers; instead of being subjects, they are rather objects of authoritarian decision-making. Authoritarian discourse implies that legal meanings are produced from above and that the existence of any dispute, questioning, legitimate disagreement, or construction of the law from the bottom-up is unthinkable. ${ }^{3}$

\section{II.}

I consider as particularly problematic the all-pervading notion of Iura novit curia, the idealistic principle of Continental law that the "judge knows the law" and must apply the appropriate legal rule regardless of whether either party cited it to the court. ${ }^{4}$ This principle, taken too seri-

\footnotetext{
${ }^{1}$ Siniša Rodin, 'Discourse, Authority in European and Post-Communist Legal Culture' (2005) 1 Croatian Yearbook of European Law and Policy 1, 7-8. (footnotes omitted)

${ }^{2}$ See chapters in Neil MacCormick and Robert S. Summers (eds), Interpreting Statutes: A Comparative Study (Aldershot, Dartmouth 1991) (although the degree of the discursive nature of judicial decisions differs, where at one pole stands the common law system, and at the other the French system, all courts work on the assumption that their decisions are "right").

${ }^{3}$ I take my inspiration from Joseph Vining, The Authoritative and the Authoritarian (The University of Chicago Press, Chicago and London 1986).

${ }^{4}$ On this, cf., for example, J.A. Jolowicz, 'Da mihi factum dabo tibi jus: a problem of demarcation in English and French law' in Peter Feuerstein and Clive Parry (eds), Multum non multa: Festschrift für Kurt Lipstein (C.F. Müller, Heidelberg 1980) 79, 84.
} 
ously and too literally, deeply influences the self-perception of the postCommunist judiciary.

One of the effects of the principle Iura novit curia is that, while the parties before a Continental court have the duty to raise issues of fact, they are not obliged to raise issues of law because the court is itself obliged to do that even without the litigants' assistance. ${ }^{5}$ As a consequence, pleadings to trial courts in most Continental countries are quite brief, without major excursus into legal issues; after all, it is the judge who is supposed to supply the relevant rule. In contrast, in the systems of the common law culture (which is typically more pragmatic), the judges have a more passive role, and greater responsibility is placed on parties not only for providing issues of fact, but also for arguing the issues of law. This is so because in constructing their opinions, Anglo-American judges draw heavily upon the parties' competing arguments as to what the "correct" statement of the law is. ${ }^{6}$

In Western Europe, the principle that the judge knows the law is not taken literally. Appeals in Western Europe tend to be longer and more elaborate when issues of law are controversial. This is so because the basic, and often the only, reason for an appeal, and accordingly the main focus of the appellant's brief, is to persuade the higher court that their interpretation of the law is correct and their opponent's (or the lower court's) interpretation is incorrect. In contemporary Continental culture, the judges technically "know" the law, but they often need the parties' attorneys to help them find the relevant provision and to determine its best reading. ${ }^{7}$

\section{III.}

The ECJ has ruled that in each particular Member State the maxim Iura novit curia applies in relation to European law to the extent that, in a similar procedural situation, it would apply in relation to that State's domestic law. In other words, in those systems which adhere to the principle Iura novit curia, the courts should apply European law irrespective of the fact that no party raises the issue. The ECJ's decision is a direct consequence of the fact that European law recognises the autonomy of Member States' procedural law. ${ }^{8}$

\footnotetext{
${ }^{5}$ On the Western European approach to the duty/option of the parties to argue legal issues, cf., for example, Isaak Meier, Iura novit curia: die Verwirklichung dieses Grundsatzes im schweizerischen Zivilprozessrecht (Schulthess Polygraphischer Verlag, Zürich 1975) 135.

${ }^{6}$ For the reasons behind this, cf. Mirjam R. Damaška, The Faces of Justice and State Authority. A Comparative Approach to the Legal Process (Yale, New Haven 1986) 139.

${ }^{7}$ Cf. Meier (n 5).

${ }^{8}$ See Joined Cases C-430/93 and 431/93 Jeroen Van Schijndel and Johannes Van Veen $v$. Stichting Pensioenfonds voor Fysiotherapeuten [1995] ECR I-4705. Cf. para 15: "in proceedings concerning civil rights and obligations freely entered into by the parties, it is for the national
} 
In post-Communist countries, the principle Iura novit curia is taken more seriously than in Western Europe, a fact which, on the surface, might be cause for encouragement because their courts (both trial and appellate) should in principle apply Community law even if no party refers to it (with the exception of supreme courts, since they are generally required to address only the issues specified in the extraordinary appeal and cannot go beyond them).

During the Communist era in Central Europe, idealistic readings of this principle for practical purposes drove the argument of law out of parties' pleadings. According to the leading Czechoslovak commentary on civil procedure, law cannot be subject to judicial recognition during the proceedings before the court; it must be known to the court in advance of the dispute arising. "The knowledge of law must be made by the [judicial] body itself; it is possible to say prior to [civil] proceedings and beyond these proceedings." ${ }^{9}$ No cooperation on the law's finding was necessary; moreover, it would prove harmful, as the parties would interfere with the court's exclusive domain. An additional reason why, during the Communist era, no help was needed from the parties in constructing the law was the fact that few parties were represented by a lawyer. ${ }^{10}$ Moreover, the fact that scant attention was paid to the attorneys' arguments fits nicely in this picture of the socialist application of law because Communist legal systems claimed that no party should gain an advantage from having a better lawyer. ${ }^{11}$

This approach mirrored the Communist authoritarian approach to the law, which is in fundamental contradiction to the discursive authoritative approach to law that prevailed meanwhile in Europe. Let us recall that, by an authoritarian approach, I mean the approach whereby legal answers can be constructed solely in a single way from the top of the system, the top holding "a social monopoly over determining the meaning of legal and political language" and "communicating it downward." 12

court to apply [Articles of the EC Treaty] even when the party with an interest in the application of those provisions has not relied on them, where domestic law allows such application by the national court", and paragraph 22 , which logically corresponds to paragraph 15: "Community law does not require national courts to raise of their own motion an issue concerning the breach of provisions of Community law where examination of that issue would oblige them to abandon the passive role assigned to them by going beyond the ambit of the dispute defined by the parties themselves and relying on facts and circumstances other than those on which the party with an interest in the application of those provisions bases his claim."

${ }^{9}$ Josef Rubeš and others, Občanský soudní rád. Komentár r [Code of Civil Procedure. Commentary] (Orbis, Praha 1970) 447. (emphasis added)

${ }^{10}$ ibid 455, where a Communist scholar does not seem even to expect that it was also possible for a party to be represented by a competent lawyer who might provide a qualified legal opinion to the court.

${ }^{11}$ Sbírka rozhodnutí československých soudů [Collection of Decisions of the Czechoslovak Courts] (1949) p 1.

12 Rodin (n 1) 7. 
The authoritarian approach to law, combined with formalist textual positivism and the ideology of the bound judicial application of law, accords to the judge an exclusive role in constructing the meaning of the law. This is so because (1) the application of law is conceptually viewed as the resolution of easy cases by the court, which does not, in that process, require the assistance of either party (formalist aspect), ${ }^{13}$ and (2) the construction of the law is the result of a top-down process, where parties are the addressees of the result of construction rather than direct or indirect participants in that construction (authoritarian aspect).

IV.

One phenomenon almost unknown in the Western world appeared in the Socialist states of Central Europe. Following the Soviet model ${ }^{14}$ and the emphasis on centralism and formalism, in all Central European countries during Communist rule, the supreme court had the power to issue guidelines and interpretative statements dealing with important legal questions, which were done in abstracto, without any case pending before the court. In some states, such directives were formally binding on the lower courts. Many of the directives were long treatises analysing the correct and incorrect applications of the specific law by lower courts within some period of time without taking into account the particulars of the case at hand. ${ }^{15}$

Lacking proper interactions between legal scholarship and the judiciary, these statements in a sense served as a substitute for them, attached to a strong and, of course, centralised and formal authority. One of the rare occasions when the judges in socialist Central Europe could speak freely (1968 Prague Spring) revealed that this very power of the supreme courts was considered to be a danger to judicial independence. ${ }^{16}$

Surprisingly enough, old-fashioned traditional ideas about precedents still dominate judicial and legal discourse. ${ }^{17}$ Instead of precedent,

\footnotetext{
${ }^{13}$ Rubeš (n 9) 455 (claiming that "as legal professionals, judges must know their legal order, and no one can claim that it would be impossible to know all the laws").

${ }_{14}$ On Soviet interpretative statements, cf. W.E. Butler (tr), Akmal Kh. Saidov, Comparative Law (Wildy, Simmonds \& Hill, London 2003) 206.

${ }^{15}$ In Hungary, cf. a critical evaluation from the point of sources of law, P. Schmidt, 'Konstitucionno-pravovye voprosy sistemi istochnikov prava VNR' [Constitutional Problems of the Hungarian System of Sources of Law] (1985) 27 (1-2) Acta Juridica Academiae Scientiarum Hungaricae 133-160, 146-148. In Poland, cf. Maria Jansen (tr), Andrzej Rzepliński, Die Justiz in der Volksrepublik Polen (Vottorio Klostermann, Frankfurt am Main 1996) 163 ff.

${ }^{16}$ Andrej Bajcura, 'Výsledky ankety o postavení sudcov' [The Results of the Poll on the Status of Judges] (1968) 51 Právný obzor 834, 835.

17 Frank Emmert, 'The Independence of Judges - A Concept Often Misunderstood in Central and Eastern Europe' (2002) 3 European Journal of Law Reform 405.
} 
all Central European legal systems continue to use interpretational statements, a specific instrument of unbound judicial law-making par excellence. The statements are still issued by supreme courts on a certain legal issue in order to unify the conflicting case law, without any real-life case pending before the supreme court.

Unlike the situation in some states prior to 1990, at present such statements are not formally binding, though they naturally possess a high degree of persuasive force throughout the judicial system. The statements do not have a direct impact on any individual case, because they are decided in abstracto, on the proposal of the court, the minister of justice, or like authorities, when these bodies opine that the interest of uniform case law so demands. ${ }^{18}$ In Hungary, the only system with a preCommunist tradition of this abstract judicial law-making, these so-called uniformity decisions are even formally binding, so that the lower courts must follow the interpretative directions found therein. ${ }^{19}$

Western judges react to this post-Communist institution with a mixture of surprise and embarrassment, ${ }^{20}$ because they view that it lies in conflict with their ideal that the judiciary makes law only through deciding cases, "interstitially," as Justice Holmes once famously noted, ${ }^{21}$ not through making law in abstracto. Thus, it is possible to argue that the continuing adherence to this institution confirms what the post-Communist systems understand by the notion of judicial law-making and

${ }^{18}$ In the Czech Republic, the competence to request such a statement is vested, inter alia, in the Minister of Justice, see art 123 (3) and art 14 (3) of the Act on the Judiciary, of 30 November 2001 no 6/2002 Sb. [Official Gazette]. Similarly in Slovakia, see art 21 (3) and art 23 of the Act on the Judiciary of 9 December 2004 no 757/2004 Z.z. [Official Gazette]. In Poland, the Supreme Court's resolutions are requested, inter alia, by the Spokesman for Citizens' Rights, the Public Prosecutor General or, within his/her competence, by the Spokesman for the Insured. See art 60 (2) the Act on the Supreme Court of 23 November 2002, Dz.U. Nr 101 of 2002, item 924, available in English at<http://www.sn.pl/english/ sadnajw/index.html> accessed 15 March 2006.

19 See Articles 24-25 of the Act LXVI of 1997 on the Organization and Administration of the Courts (basic information in English available at <http://www.lb.hu/english/index.html $>$. Cf. Árpád Erdei, 'Law of Criminal Procedure', in Attila Harmathy (ed), Introduction to Hungarian Law (The Hague/London/Boston 1998) 211.

${ }^{20}$ As did German judges in their reports on the Czech judiciary of 2003. All of them actually criticised this institution, which according to them is a waste of the Supreme Court's energy. Moreover, they noted that it solves a question in abstracto, without proper judicial testing at the lower levels. 'Souhrn návrhů pro českou justici v oblasti organizace soudnictví, civilního a trestniho řizení' [A Set of Proposals for the Czech Judiciary in the Area of the Organisation of the Judiciary and Civil and Criminal Procedure], Twinning Project CZ 01/IB/JH/01 Judicial Reform and Court Management Czech Republic - Germany - United Kingdom (not published, on file with the author).

${ }^{21}$ Southern Pac. Co. v. Jensen, 244 U.S. 205, 221 (1917) (Holmes, J., dissenting: "I recognize without hesitation that judges must and do legislate, but they do so only interstitially; they are confined from molar to molecular motions."). 
demonstrates why they have difficulties in understanding proper judicial law-making. In addition, a minister's power to request such a statement might be easily misused to intervene in politically sensitive cases pending in lower courts.

Authoritarian discourse might face serious difficulties with the internalising of judicial law-making via precedent proper, based on interactions between legal scholarship, private parties and the judges of law courts, both those at the lower echelons and those of the high courts who possess the final authority to say what the law is in an individual case. That is why authoritarian discourse shows a clear preference for centralised judicial law-making by supreme courts without listening to anyone, including the lower courts. Politically, interpretational statements might be a welcome tool for politicians to model their laws via judicial abstract statements by inviting judges to decide on some particular problem, and sometimes by punishing those judges who do not follow the rules of the game. ${ }^{22}$

\section{V.}

It is clear that the authoritarian approach to law still governs postCommunist legal discourse. The principle Iura novit curia appears to function as a barrier separating the parties before the court from the judge. An intriguing vicious circle is at work here. The legal arguments made by the parties' attorneys in their briefs rarely exceed a few paragraphs, and almost never include proper citations to the literature and case law, thus providing the judge with little useful information. Perhaps it is because most of the legal arguments made by the parties are worthless that the judge often ignores those rare arguments that are valuable and which might help him in finding the relevant case law, useful comparative materials from abroad, etc. Instead, the judge only elaborates the court's own legal theories. ${ }^{23}$

Thus, when taken too seriously, the principle Iura novit curia becomes self-fulfilling, discouraging both the parties from contributing to

\footnotetext{
${ }^{22}$ The Chief Justice of the Czech Supreme Court was dismissed in February 2006 by the President after a proposal by the Minister of Justice. One of the crucial reasons was the fact that the Chief Justice did not assure "unification of law" via judicial interpretational statements. (See the press release of the President of 1 February 2006) <http://www.hrad. cz> accessed 23 March 2006 (official website of the Czech President). The Chief Justice's dismissal was declared unconstitutional by the Czech Constitutional Court's ruling of 12 September 2006 as being in conflict with the principle of judicial independence (see II. ÚS 53/06, n.y.r., available in Czech at the Court's website <http://www.concourt.cz>).

${ }^{23}$ This approach is often criticised by the Czech Constitutional Court which has repeatedly insisted that ordinary courts have to address every legal argument made by either party. Cf. the decision III. ÚS 176/96, Collection of decisions of the Czech Constitutional Court (hereinafter 'Collection'), vol 6, pp $151 \mathrm{ff}$.
} 
the court's legal reasoning and the judges from drawing upon the attorneys' expertise. The effective application of EU law necessarily requires parties to be engaged in constructing the courts' arguments, which brings the European systems closer to the Anglo-American discursive conception of law in which the court's legal conclusions are reached in a discursive manner.

As the Czech Constitutional Court proclaimed recently:

Unless it is the case when the legal solution is a direct result of the text of the law, the general court must explain sufficiently its legal reasoning, if possible by quoting published case law or doctrinal opinions. If the party argues by doctrinal opinions or case law, the general court must address the opinions mentioned in those sources, including the possibility that the general court explains why it does not consider those opinions significant for the case. Only in this way might the opinion of the court be persuasive and only in this way might it justify that the correct interpretation is the interpretation selected by the court. ${ }^{24}$

The principle that the judge knows the law does not require that this knowledge be acquired without any assistance from the parties, as the authoritarian (post-) Communist conception of law posits. If one understands law as discourse (and I claim that the judicial conception of law must understand law as discourse - the conflict of parties' views over both fact and law), then a judge must explain why his reading of the law is the best interpretation when faced with other interpretations offered by the parties, conflicting case law, or legal literature.

Judges are the final authoritative interpreters not because they are omniscient and infallible, but because of their function and status within the legal system. The authority of the judge to decide the case "correctly" is ultimately tested by real-life cases. If understood from this perspective, abstract judicial interpretational statements are not only against the very core of authoritative legal discourse, they are also in conflict with the basic tenets of the separation of powers.

\footnotetext{
${ }^{24}$ Decision no. I. ÚS 403/03 of 17 August 2005, not yet reported, available in Czech at <http://www.judikatura.cz>. (emphasis added)
} 